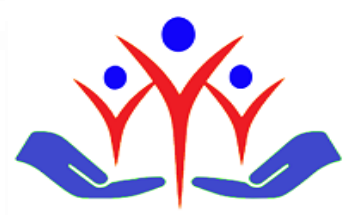

\title{
Evaluation of clinical features and the factors related to nutrition in home care patients with pressure ulcer
}

Basınç ülseri olan evde bakim hizmeti alan hastaların klinik özellikleri ve beslenme ile ilişkili faktörlerin değerlendirmesi Ozisik Karaman

a Department of Neurology, School of Medicine, Kutahya Health Sciences University, Kutahya, Turkey

b Department of Neurology, Izmir Bozyaka Training and Research Hospital, University of Health Sciences, Izmir, Turkey

${ }^{\mathrm{c}}$ Department of Neurology, School of Medicine, Canakkale Onsekiz Mart University, Canakkale, Turkey

\begin{abstract}
Introduction: In this study, we aimed to determine the demographic and clinical characteristics of patients with pressure ulcers who received home health care in Kutahya city and to investigate the relationship between the factors related to nutrition and pressure ulcer grades.

Methods: This study is designed as a retrospective and cross-sectional. The files of 500 patients who were registered at home health services unit of Kutahya Health Sciences University Training and Research Hospital between December 2016 and May 2017 were reviewed retrospectively. Of these, sixty-three patients with pressure ulcers were included in the study.

Results: In this study, $26(41.3 \%)$ were male and $37(58.7 \%)$ were female. The mean age of the patients with pressure ulcers was $74.41 \pm 12.30$ (years). 36 patients $(57.1 \%)$ had cerebrovascular disease, 5 patients $(7.9 \%)$ had dementia, 9 patients (14.3\%) had malignancy, 8 patients (12.7\%) had osteoarthritis, 4 patients $6.3 \%$ ) had peripheral vascular disease, and 1 patient (1.6\%) had previous traffic accident. The majority (62.1\%) were neurological disease-sequenced and nursing-care group. When all the patients were examined, the region with the most pressure was the sacrum $(35.3 \%)$. Hemoglobin level was found to be related to pressure ulcer grade (One-way ANOVA, $\mathrm{p}=0.019$ ). There was no significant relationship between other nutrition-related parameters and pressure ulcer stage.

Conclusion: Patients with cerebrovascular disease constitute a significant proportion of patients receiving home care services. Low hemoglobin increases the severity of the pressure ulcer. Therefore, determining risk factors that contribute to pressure ulcer formation and efforts to prevent them should be the primary target of the home health care unit.

Keywords: Pressure ulcer, home care services, nutritional status
\end{abstract}

\section{$\ddot{\mathbf{O} z}$}

Giriş: Bu çalışmada, Kütahya ilinde evde sağlık hizmeti alan basınç ülserli hastaların demografik ve klinik özelliklerini belirlemenin yanında beslenme ile ilișkili olan faktörlerin basınç ülser dereceleriyle ilișkisinin incelenmesi amaçlandı.

Yöntem: Bu çalışma retrospektif ve kesitsel niteliktedir. Aralık 2016 ve Mayıs 2017 tarihleri arasında Kütahya Sağlık Bilimleri Üniversitesi Evliya Çelebi Eğitim ve Araştırma Hastanesi evde sağlık hizmetleri biriminde kayıtlı ve düzenli olarak evde sağlık hizmeti sunulan 500 hastanın dosyaları retrospektif olarak tarandi. Bunlardan basınç ülserli olan 63 hasta çalışmaya dahil edildi.

Bulgular: Çalışmaya $26(\% 41,3)$ erkek ve $37(\% 58,7)$ kadın olmak üzere toplam 63 hasta dahil edildi. Basınç ülseri olan hastaların yaş ortalamaları 74,41 $\pm 12,30$ (yıl) bulundu. Hastaların 36'sı (\%57,1) serebrovasküler hastalığa, 5'i (\%7,9) demansa, 9'u (\%14,3) maligniteye, 8'i (\%12,7) osteoartrite, 4'ü $(\% 6,3)$ periferik vasküler hastalığa, 1'i $(\% 1,6)$ geçirilmiş trafik kazasına sahip olup, büyük kısmı $(\% 62,1)$ nörolojik hastalık sekeli nedeni ile bakım hastası olan gruptur. Tüm hastalar incelendiğinde en fazla bası yeri olan bölge sakrumdu $(\% 35,3)$. Laboratuvar değerlerinden hemoglobin düzeyinin bası derecesi ile ilişkili olduğu görüldü (Tek yönlü varyans analizi, p=0,019). Beslenme ile ilişkili diğer parametreler ile basınç ülser evresi arasında anlamlı ilişki saptanmadı.

Sonuç: Serebrovasküler hastalık sekelli hastalar evde bakım hizmeti alan hastaların önemli bir kısmını oluşturmaktadır. Düşük hemoglobin basınç ülser şiddetini arttırmaktadır. Bu nedenle basınç ülseri oluşumuna katkıda bulunan risk faktörlerinin belirlenmesi ve bunların önlenmesine yönelik çabalar evde sağlık hizmeti biriminin öncelikli hedefi olmalıdır.

Anahtar Kelimeler: Bası ülser, evde bakım hizmetleri, beslenme durumu

\begin{tabular}{|c|c|c|c|c|}
\hline Received & Accepted & Published Online & Corresponding Author & E-mail \\
\hline September 19, 2020 & January 7, 2021 & April 3, 2021 & Mustafa Cetiner, MD & $\underline{\text { drcetiner76@ gmail.com }}$ \\
\hline Correspondence & \multicolumn{2}{|c|}{ Bahçelievler mahallesi, Eryiğit sokak, No:24, Ladin sitesi.A-blok, K: 3, D- 13 Kütahya, Turkey } \\
\hline
\end{tabular}




\section{Introduction}

The most critical factor in the development of pressure ulcers is constant uneven pressure on the tissue [1]. In studies, it has been shown that, factors such as decrease in mobility, changes in sensory perception, humidity, friction/irritation, old age, malnutrition, hemodynamic changes, comorbid diseases, and stress cause pressure ulcers in hospitalized and home care patients [2,3].

In previous studies, patients with chronic neurological diseases, trauma sequelae, cancer, peripheral artery disease and diabetes in home care and long-term care units have been shown to be at high risk for the development of pressure ulcers, and the importance of recognizing patients followed in these centers with these diagnoses in terms of preventing pressure ulcers was emphasized [4-6].

Increased severity of pressure ulcers in patients who cannot get appropriate treatment and care increases the risk of infection and mortality [7]. The pressure ulcer is a significant problem regarding all the steps of healthcare services, especially home care. The prevalence of pressure ulcers among patients receiving home care is $9.1-18.8 \%$ [8,9]. In single-center studies performed in our country, the incidence has been reported between 22.8 and $42.1 \%[2,10,11]$. The pressure ulcer is an important health problem that increases the mortality and morbidity risk, decreases the quality of life and has high treatment costs. Since it is preventable, it is crucial to identify patients at risk [2].

Malnutrition is one of the well-known risk factors for the development of pressure ulcers in hospitals and nursing homes [12-15]. Similarly, Lizaka et al. reported that malnutrition is a risk factor for the development of pressure ulcers in patients who are under home care follow-up [16].It has been shown that providing the necessary nutritional supplements after early detection of malnutrition reduces the development of pressure ulcers and increases the healing of existing pressure injuries [15]. Hydration and nutrition play an important role in skin and tissue vitality and aid in tissue repair in pressure ulcer management [14]

Therefore, appropriate screening for nutritional status, collaboration with a specialist dietitian, and appropriate nutritional support should be important aspects of pressure wound management in patients at risk [17].In this study, we aimed to evaluate the clinical and demographic characteristics of the patients followed by the home care services unit of Kutahya Health Sciences University and to investigate the relationship between nutrition-related laboratory values and pressure ulcer grade.

\section{Methods}

This study is designed as a retrospective and cross-sectional study. The data of 500 patients who were admitted to Kutahya Health Sciences University Training and Research Hospital home care services unit between December 2016 and May 2017 and received home care were retrospectively reviewed. Of these 500 patients, sixty-three patients with pressure ulcers were included in the study.

Age, gender, body mass index (BMI), primary diagnosis causing home care services, comorbid diseases, diet, physical activity level, location, number and grade of pressure ulcers were recorded. Nutritional laboratory data of the patients (Albumin, Total Protein, Red Blood Cell Count, Hemoglobin $(\mathrm{Hgb})$ and Iron $(\mathrm{Fe})$ were recorded from the hospital database.

Patients with a body mass index (BMI) of $18.5 \mathrm{~kg} / \mathrm{m} 2$ were considered as underweight, patients with $\geq 25 \mathrm{~kg} / \mathrm{m}^{2}$ were considered as overweight, patients between 18.5 and $25 \mathrm{~kg} / \mathrm{m}^{2}$ were considered as normal, and patients with $\geq 30 \mathrm{~kg} / \mathrm{m}^{2}$ were considered as obese. Types of nutrition were recorded as; oral nutrition or percutaneous endoscopic gastrostomy (PEG). According to the limitations of physical activity, patients who were in bed all day were considered as bed-dependent, who had limited walking ability and supported their weight with instruments such as wheelchair were considered as semi-dependent, who were walking with support one or walk without support were classified as mobile.

Location and number of pressure ulcers were evaluated. It was divided into four grades according to the degree and depth of tissue damage in pressure ulcers. If there was only erythema, it was classified as grade 1; if there was superficial ulceration up to dermis, it was classified as grade 2 ; if there was deep ulceration that progressed to the muscle and bone in the compression area, it was classified as grade 3 ; if it has progressed bones, joints and body cavities it was classified as grade 4 [18]. The staging was performed according to the highest grade in patients with pressure ulcers in more than one region.

\section{Ethical Approval}

The study was approved by the Canakkale Onsekiz Mart University Ethics Committee (Decision no: 2016-21) and an informed consent form was obtained from all patients included in our study.

\section{Statistical Analysis}

Statistical analysis was performed using SPSS 24.0 (IBM Corp; Armonk, NY, USA). Continuous variables that have normal distribution were expressed as mean \pm standard deviation, abnormally distributed variables were expressed as median (minimum-maximum). Descriptive statistics for categorical variables were expressed as number (n) and percentage (\%). One-way ANOVA and Kruskal-Wallis test were used to compare the groups. Post-Hoc analysis was performed with Tukey test. The level of statistical significance was set at $\mathrm{p}<0.05$.

\section{Results}

Sixty-three patients with pressure ulcers were included in our study. Twenty-six of the patients were male (41.3\%), and 58.7\% ( $\mathrm{n}=37)$ were female. Pressure ulcer was present in $12.6 \%$ of the 500 patients who were followed in the home care services unit between December 2016 and May 2017. The age range of the patients was 37-99 years. The mean age was $74.41 \pm 12.30$ years. 
The primary diagnoses of the patients who were under home care follow-up are as follows: cerebrovascular disease (n: 36; $57.1 \%)$, malignancy (n: 9; $14.3 \%$ ), osteoarthritis (n: $8 ; 12.7 \%$ ); dementia (n: $5 ; 7.9 \%$ ), peripheral vascular disease (n: $4 ; 6.3 \%$ ) and sequel changes secondary to traffic accidents (n: $1 ; 1,6 \%) .62 .1 \%$ of the patients were under home care follow-up due to neurological diseases.31 patients (49.2\%) had hypertension (HT), 25 patients (39.7\%) had diabetes mellitus (DM) and 23 patients $(36.5 \%)$ had cardiovascular disease (CVD). When the patients were evaluated according to the limitations of physical activity; 2 patients (3.2\%) needed support while walking, seven patients (11.1\%) were semi-dependent, and 54 patients $(85.7 \%)$ were bed-dependent (Table 1). The number of patients fed with PEG was $7(11.1 \%)$, and the number of patients who could be fed orally was $56(88.9 \%)$. When patients were grouped according to body mass index (BMI), two patients (3.2\%) were underweight, 38 patients $(60.3 \%)$ were normal, 14 patients $(22.2 \%)$ were overweight, and nine patients (14.3\%) were obese. Demographic and clinical characteristics of the patients with pressure ulcers are presented in Table 1.

Table 1. Demographic, clinical and laboratory characteristics of patients with pressure ulcers.

\begin{tabular}{|c|c|}
\hline Age (years), mean $\pm \mathrm{SD}$ & $74.41 \pm 12.30$ \\
\hline \multicolumn{2}{|l|}{ Gender, n (\%) } \\
\hline - Female & $37(58.7)$ \\
\hline - Male & $26(41.3)$ \\
\hline \multicolumn{2}{|l|}{ Diagnosis of patients, $\mathrm{n}(\%)$} \\
\hline - Cerebrovascular Disease & $36(57.1)$ \\
\hline • Malignancy & $9(14.3)$ \\
\hline - Osteoarthritis & $8(12.7)$ \\
\hline - Dementia & $5(7.9)$ \\
\hline - Peripheral vascular disease & $4(6.3)$ \\
\hline -Traffic accident & $1(1.6)$ \\
\hline \multicolumn{2}{|l|}{ Comorbid diseases, $\mathrm{n}(\%)$} \\
\hline • HT & $31(49.2)$ \\
\hline - DM & $25(39.7)$ \\
\hline - Cardiovascular disease & $23(36.5)$ \\
\hline - Multiple comorbidities & $21(33,3)$ \\
\hline \multicolumn{2}{|l|}{ Activity, n (\%) } \\
\hline - Mobile & - \\
\hline - Walking with help & $2(3.2)$ \\
\hline - Chair-dependent & $2(3.2)$ \\
\hline - Bed-dependent & $54(85.7)$ \\
\hline \multicolumn{2}{|l|}{ Type of nutrition, n (\%) } \\
\hline - Oral & $56(88.9)$ \\
\hline - Gastrostomy & $7(11.1)$ \\
\hline \multicolumn{2}{|l|}{ BMI, n (\%) } \\
\hline - Underweight & $2(3.2)$ \\
\hline • Normal & $38(60.3)$ \\
\hline - Overweight & $38(60.3)$ \\
\hline - Obese & $9(14.3)$ \\
\hline
\end{tabular}

SD: standard deviation, n:number, HT: hypertension, DM: diabetes mellitus, BMI: body mass index

When the pressure ulcers were evaluated according to their localization; 30 patients' ulcers $(47.6 \%)$ were located in the sacral region followed by, coccyx in 16 patients $(25.3 \%)$, heel in 14 patients $(22.2 \%)$ in, trochanter in 12 patients $(19 \%)$, ischium in 8 patients $(12 \%)$ and other (elbow, lateral malleolus, etc.) regions in 5 patients $(7.9 \%)$ Twenty-two patients $(34.9 \%)$ had pressure ulcers on two or more sites. When the pressure ulcers were graded according to the degree of tissue damage, ten patients $(15.9 \%)$ were grade 1,37 patients $(58.7 \%)$ were grade 2,15 patients $(23.8 \%)$ were grade 3 and one patient $(1.6 \%)$ grade 4 . The pressure ulcer characteristics of the patients are presented in Table 2.

Table 2. Characteristics of pressure ulcer patients

\begin{tabular}{|c|c|}
\hline Pressure ulcer localizations & $\mathbf{n}(\%)$ \\
\hline Sacrum & $30(35.3)$ \\
\hline Coccyx & $16(18.8)$ \\
\hline Heel & $14(16.5)$ \\
\hline trochanter & $12(14.1)$ \\
\hline Ischial & $8(9.4)$ \\
\hline Other (elbow, lateral malleolus, etc.) & $5(5.9)$ \\
\hline Pressure ulcer in two or more localizations & $22(34.9)$ \\
\hline \multicolumn{2}{|l|}{ Pressure ulcer stage, n (\%) } \\
\hline Stage 1 & $10(15.9)$ \\
\hline Stage 2 & $37(58.7)$ \\
\hline Stage 3 & $15(23.8)$ \\
\hline Stage 4 & $1(1.6)$ \\
\hline
\end{tabular}

The mean values of serum albumin, total protein and red blood cell count were $3.10 \pm 0.63 \mathrm{~g} / \mathrm{dL}, 6.34 \pm 0.79 \mathrm{~g} / \mathrm{dL}$, and $44.27 \pm 0.70\left(\mathrm{x} 10^{6} / \mu \mathrm{L}\right)$, respectively. Low level of albumin was detected in 43 patients $(68.3 \%)$, while low level of total albumin was present in 28 patients (44.4). Also, red blood cell count was low in 35 patients (55.6) whilst low Hgb values were detected in 37 patients (58.7) and low level of $\mathrm{Fe}$ was present 51 patients $(81 \%)$ (Table 3$)$.

Table 3. Number and percentage of patients with low laboratory values associated with nutrition

\begin{tabular}{ll}
\hline Albumin $(\downarrow)$ & $43(68.3 \%)$ \\
Total Protein $(\downarrow)$ & $28(44.4 \%)$ \\
Red blood cell $(\downarrow)$ & $35(55.6 \%)$ \\
Hemoglobin $(\downarrow)$ & $37(58.7 \%)$ \\
Fe $(\downarrow)$ & $51(81 \%)$ \\
\hline
\end{tabular}

Fe: Iron

$\mathrm{Hgb}$ level was found to be related to pressure grade $(\mathrm{p}=0.01)$. In the post hoc (Tukey) analysis, the mean hemoglobin in grade 1 was statistically significant compared to grade $2(\mathrm{p}=0.020)$ and grade $3(\mathrm{p}=0.034)$. Although there was no statistical significance, patients with Grade 1 pressure ulcers had higher red blood cell count $(\mathrm{p}=0.057)$. There was no significant relationship between pressure ulcer grades and laboratory parameters except hemoglobin level. The relationship between laboratory parameters and pressure ulcer grades is presented in Table 4 . 
Table 4. Comparison between laboratory values and pressure ulcer stage

\begin{tabular}{|c|c|c|c|c|}
\hline & $\begin{array}{c}\text { Grade } 1 \\
(\mathrm{n}=\mathbf{1 0}, \mathbf{1 5 . 9 \%})\end{array}$ & $\begin{array}{c}\text { Grade } 2 \\
(\mathrm{n}=\mathbf{3 7}, \mathbf{5 8 . 7 \%})\end{array}$ & $\begin{array}{c}\text { Grade } 3-4 \\
(n=16,25.4 \%)\end{array}$ & $\mathbf{P}$ \\
\hline Albumin (g/dL), & $3.40 \pm 0.56$ & $3.03 \pm 0.60$ & $3.07 \pm 0.71$ & $0.267 \#$ \\
\hline Total Protein $(\mathrm{g} / \mathrm{dL})$ & $6.47 \pm 0.81$ & $6.30 \pm 0.84$ & $6.36 \pm 0.69$ & $0.831 \#$ \\
\hline Red blood cell $\left(10^{6} / \mu \mathrm{L}\right)$ & $4.74 \pm 0.55$ & $4.15 \pm 0.59$ & $4.27 \pm 0.90$ & $0.057 \#$ \\
\hline Hemoglobin (g/dL) & $13.77 \pm 2.32$ & $11.78 \pm 1.60$ & $11.68 \pm 2.60$ & $0.019 * \#$ \\
\hline $\mathrm{Fe},(\mu \mathrm{g} / \mathrm{dL})$ & $28.50(12-210)$ & $29,00(6-287)$ & $44.00 \pm 28.36$ & $0.512 \ddagger$ \\
\hline
\end{tabular}

Fe: Iron, *:significant p value, \#One-way ANOVA, ‡Kruskal-Wallis test

\section{Discussion}

In this cross-sectional and single-center study, it was aimed to investigate the relationship between pressure ulcers and nutrition in addition to determining the characteristics of patients with pressure ulcers receiving home care services in Kutahya.

In recent studies, the mean age of patients receiving home care services was $>70$ (years) $[8,16,19]$. Similarly, the mean age of our study sample was 74.41 years. However, there was no statistically significant relationship between the development of pressure ulcers and age. Hence the female patients have more adipose tissue, they are under higher risk regarding hypoxia at the cellular level when exposed to chronic pressure [20]. In previous studies, it was also reported that the majority of the patients were female $[2,5,10,21]$. However, many studies emphasized that there is no gender difference [22]. In this study, women were in the majority with a rate of $58.7 \%$.

In the study of Capon et al., showed that patients with neurological diseases and sequel secondary to trauma are associated with the development of pressure ulcers [6]. History of cerebrovascular disease compromises an important part of home care. Both forming the majority of the study sample, $45.1 \%$ of the patients in the study of Sahin et al., and $49 \%$ of the patients in the study of Akturk et al. had a history of CVD [10,11]. In this study, we had 36 (57.1\%) patients with CVD. A total of 54 patients (85.7\%) were bed-dependent and had a high rate of movement restriction.

Comorbid diseases are known to be an important risk factor in the development of pressure ulcers. DM, HT, and chronic heart disease disrupt tissue perfusion and facilitate the development of pressure ulcers and increase the risk [1,5]. In this study, HT was present in 49.2\% of the patients, DM in $39.7 \%$ and cardiovascular disease in $36.5 \%$ of the patients. In this study, patients with pressure ulcers had a high incidence of comorbid diseases, and $33.3 \%$ of patients had more than one comorbidity. This was considered as an important risk factor in the development of pressure ulcers. Considering multiple factors and a more versatile approach would be more useful in the follow-up of these patients.

In previous studies, it has been reported that the localization of pressure ulcers is most frequently in the sacral region [23]. The fact that patients stay in supine position and the sacral region remains under pressure as a result of inadequate rehabilitation are the main causes of the sacral region being most affected [1]. In this study, pressure ulcers were found most frequently in the sacral region (35.3\%). Other localizations were coccyx (18.8\%), heel (16.5\%), trochanter $12(14.1 \%)$, and ischia $8(9.4 \%)$. According to the depth of the lesion, grade 1-2 (74.6\%) pressure ulcers were most frequently observed (Table 2). Our results were consistent with the literature. Grade 1 and 2 pressure ulcers are treated conservatively. For this reason, the patients who are followed by the home care services unit should be examined for pressure ulcers. The care giving relatives of the patients at home should be informed about the issue. Early-stage pressure ulcers should be followed up and treated with adequate conservative approaches to prevent any progression.

Malnutrition is a common clinical condition in elderly patients in need of home care. Therefore, it is essential to screen the patients for malnutrition risk [24]. Adequate nutrition is vital for the prevention of pressure ulcers hence the opposite may prevent healing when a pressure ulcer develop $[25,26]$. In a study that examined the relationship between BMI and patients with and without pressure ulcers, there was not any statistical significance [27]. However, under BMI 24, seniors are at risk of malnutrition [28]. Since 63.5\% of the patients in our study had a BMI of less than 24 , a significant proportion of our patients were at risk of malnutrition. Patients with nutritional disorders have low albumin levels, and the risk of pressure ulcers is increased in the presence of hypoalbuminemia. At the same time, nutritional disorder reduces skin elasticity and causes anemia, leading to decreased tissue oxygenation. Although low hemoglobin levels are associated with decreased oxygen in tissues and associated with pressure ulcer development, there are some studies showing no relationship between hemoglobin level and pressure wound development [29, 30]. In the study of Neloska et al., hypoproteinemia, hypoalbuminemia, and anemia were found more frequently in patients with pressure ulcers [21]. In this study, nutrition-related laboratory values were lower than normal in a significant number of patients. Albumin (68.3\%), total protein (44.4\%), red blood cell (55.6\%), Hgb (58.7\%) and Fe (81\%) were found low. There was also a significant correlation between the grade of pressure ulcer tissue damage and $\mathrm{Hgb}$ values. Hgb value decreased significantly as the pressure ulcer grade increased. Red blood cell counts were decreased as the degree of pressure ulcers increased, although it was not statistically significant.

In this study, $63.5 \%$ of patients had a BMI lower than 24 and thus were at risk of malnutrition. These results suggest that those patients are not fed sufficiently. In this study, although the number of patients with oral nutrition is high, these patients may not be fed enough due to severe chronic diseases. Therefore, close nutritional follow-up of patients is required. 


\section{Limitations}

The limitations of our study were that it was a single-centered, cross-sectional study and there were a small number of patients. Although only Hgb level was found to be related to pressure grade, low level of albumin, red blood cell count and hemoglobin values were detected significant proportion of patients. It is important to include a large number of participants to be able to perform more robust statistical tests. Multicenter prospective studies would be helpful for the effects of nutritional factors on the development and prognosis of pressure ulcers.

\section{Conclusion}

As a result, chronic or acute neurological diseases can lead to severe physical sequelae. Pressure ulcers which affect the quality of life of both the patients and the relatives, are a significant problem in patients receiving home health care follow up for neurological diseases or due to different etiologies. During the process of the solution of this problem, multiple risk factors contributing to the development of pressure ulcers should be identified and prevented as the primary objective of the home health care unit.

\section{Conflict of interest: None}

\begin{tabular}{|l|l|l|}
\hline \multicolumn{2}{|c|}{ Author Contributions } & \multicolumn{1}{c|}{ Author Initials } \\
\hline SCD & Study Conception and Design & $\begin{array}{l}\text { MC, NE, OO, SAA, } \\
\text { HIOK }\end{array}$ \\
\hline AD & Acquisition of Data & MC, SAA, OO, SCK \\
\hline AID & Analysis and Interpretation of Data & MC, HIOK, NE, OO \\
\hline DM & Drafting of Manuscript & MC, SCK, NE, SAA \\
\hline CR & Critical Revision & MC, SCK, HIOK, NE \\
\hline
\end{tabular}

\section{Financial support: None}

\section{References}

1. Ozturk A, Gurlek A, Arslan A, Firat C, Fariz A. [Our Clinical Experiences in Pressure Sore in a period of 10 years] (in Turkish). Turgut Ozal Tip Merk Derg. 2006; 13(4):243-8. https://dergipark.org.tr/tr/pub/totm/issue/13111/157965

2. Bergquist S. Pressure ulcer prediction in older adults receiving home health care: implications for use with the OASIS. Adv Skin Wound Care. 2003;16(3):132-9. http://doi.org/10.1097/00129334-200305000-00011

3. Allman RM. Pressure ulcer prevalence, incidence, risk factors, and impact. Clin Geriatr Med. 1997;13(3):42136 https://www.ncbi.nlm.nih.gov/pubmed/9227937

4. Lyman V. Successful heel pressure ulcer prevention program in a long-term care setting. J Wound Ostomy Continence Nurs. 2009;36(6):61621 http://doi.org/10.1097/WON.0b013e3181bd813e

5. Demirci Sahin A, Seyrek S, Erturk A, Bayındır Artantas A. [Pressure ulcers among home care patients and their demographic features] (in Turkish). Konuralp Med J. 2017;9(1):14-8 http://doi.org/10.18521/kts.286610

6. Capon A, Pavoni N, Mastromattei A, Di Lallo D. Pressure ulcer risk in long-term units: prevalence and associated factors. J Adv Nurs 2007;58(3):263-72 http://doi.org/10.1111/j.1365-2648.2007.04232.x

7. Khor HM, Tan J, Saedon NI, Kamaruzzaman SM, Chin AV, Poi PJ, et al. Determinants of mortality among older adults with pressure ulcers. Arch Gerontol Geriatr. 2014;59(3):536-41 https://doi.org/10.1016/j.archger.2014.07.011

8. Ferrell BA, Josephson K, Norvid P, Alcorn H. Pressure ulcers among patients admitted to home care. J Am Geriatr Soc. 2000; 48(9):1042-7 https://doi.org/10.1111/j.1532-5415.2000.tb04778.x

9. Landi F, Onder G, Russo A, Bernabei R. Pressure ulcer and mortality in frail elderly people living in community. Arch Gerontol Geriatr. 2007;44(1):217-23 https://doi.org/10.1016/j.archger.2007.01.030

10. Sikar Akturk A, Atmaca E, Zengin S, Bayramgurler D. [Prevalence and clinical features of pressure ulcers in patients receiving home health care services in the city of Kocaeli] (in Turkish). Turk derm. 2010;44:128-31 https://doi.org/10.4274/turkderm.44.128

11. Cayır Y, Avsar UZ, Avsar U, Cansever Z, Khan AS. [Characteristics of patients who receive home health services and expectations of caregivers] (in Turkish). Konuralp Med J. 2013;5(3):9-12 https://doi.org/10.18521/ktd.56044

12. Horn SD, Bender SA, Ferguson ML, Smout RJ, Bergstrom N, Taler G, et al. The national pressure ulcer long-term care study: pressure ulcer development in long-term care residents. J Am Geriatr Soc. 2004;52(3):359-67 https://doi.org/10.1111/j.1532-5415.2004.52106.x

13. Soini H, Routasalo P, Lagstrom H. Characteristics of the mini-nutritional assessment in elderly home-care patients. Eur J Clin Nutr. 2004;58(1):64-70 https://doi.org/10.1038/sj.ejcn.16017448

14. Eglseer D, Manuela Hödl M, Lohrmann C. Nutritional management of older hospitalised patients with pressure injuries. Int Wound J. 2019;16(1): 226-32 https://doi.org/10.1111/iwj.13016

15. Citty SW, Cowan LJ, Wingfield Z, Stechmiller J. Optimizing Nutrition Care for Pressure Injuries in Hospitalized Patients. Adv Wound Care (New Rochelle). 2019; 8(7): 309-22 https://doi.org/10.1089/wound.2018.0925

16. Iizaka S, Okuwa M, Sugama J, Sanada $H$. The impact of malnutrition and nutrition-related factors on the development and severity of pressure ulcers in older patients receiving home care. Clin Nutr. 2010;29(1):47-53 https://doi.org/10.10196/j.clnu.2009.05.018

17. Saghaleini HD, Dehghan K, Shadvar K, Sanaie S, Mahmoodpoor A, Ostadi Z. Pressure ulcer and nutrition. Indian J Crit Care Med. 2018;22(4):283-9 https://doi.org/10.4103/ijccm.JJCCM_277_17

18. Beger T. [Decubitus ulcers in intensive care: prevention of risk factors] (in Turkish). Intensive Care J. 2004;4(4):244-53 http://www.yogunbakimdergisi.org/managete/fu_folder/2004-04/2004-4-4-244-253.pdf 
19. Artico M, Dante A, D'Angelo D, Lamarca L, Mastroianni C, Petitti T, et al. Prevalence, incidence and associated factors of pressure ulcers in home palliative care patients: a retrospective chart review. Palliat Med. 2018;32(1):299-7 https://doi.org/10.1177/0269216317737671

20. Alves AGP, Borges JWP, Brito MA. Assessment of risk for pressure ulcers in intensive care units: an integrative review. Rev Pesqui Cuid Fundam. 2014;6(2):793-4 https://doi.org/10.9789/2175-5361.2014v6n2p793

21. Neloska L, Damevska K, Nikolchev A, Pavleska L, Petreska-Zovic B, KostovM. The association between malnutrition and pressure ulcers in Elderly in long-term care facility. Open Access Maced J Med Sci. 2016;4(3):423-27 https://doi.org/10.3889/oamjms.2016.094

22. Karahan A, A Abbasoğlu A, Işık SA, Çevik B, Saltan Ç, Elbaş NO, et a. Factors affecting wound healing in individuals with pressure ulcers: a retrospective study. Ostomy Wound Manage. 2018;64:32-9 https://doi.org/10.25270/owm.2018.2.3239

23. Anthony D, Alosaimi D, Shiferaw WS, Korsah K, Safari R. Prevalence of pressure ulcers in Africa: A systematic review and meta-analysis. J Tissue Viability 2021;30(1):137-45 https://doi.org/10.1016/j.jtv.2020.10.003

24. Cevik A, Basat O, Ucak S. [Evaluation of nutritional status and its effect on biochemical parameters in elderly people admitted to home health care services] (in Turkish). SEEAH. Med Bull 2014;48(2):132-9 https://doi.org/10.5350/SEMB.20140507030931

25. Saghaleini SH, Dehghan K, Shadvar K, Sanaie S, Mahmooodpoor A, Ostadi Z. Pressure ulcer and nutrition. Indian J Crit Care Med. 2018;22(4):283-9 https://doi.org/10.4103.ijccm.IJCCM $277 \quad 17$

26. Taylor C. Importance of nutrition in preventing and treating pressure ulcers. Nurs Older People. 2017;29(6):33-9 https://doi.org/10.7748/nop.2017.e910

27. Bergquist-Beringer S, Gajewski BJ. Outcome and assessment information set data that predict pressure ulcer development in older adult home health patients. Adv Skin Wound Care. 2011;24(9):404-14 https://doi.org/10.1097/01.ASW.0000405215.4992.a9

28. Mathus-Vliegen EM. Old age, malnutrition, and pressure sores: an ill-fated alliance. J Gerontol A Biol Sci Med Sci. 2004; 59(4): 355-60 https://doi.org/10.1093/gerona/859.4.M355

29. Kurtulus Tosun Z, Boluktas RP. [Pressure ulser prevelance and effecting factors among eldery patients in invasive care units] (in Turkish. J Turk Soc Crit Care Nurs. 2015;19(2):43-53 https://dergipark.org.tr/tr/pub/ybhd/issue/26493/278797

30. Ulker Efteli E, Yapucu Gunes U. A prospective, descriptive study of risk factors related to pressure ulcer development among patients in intensive care units. Ostomy Wound Manage. 2013;59(7):22-7 https://www.ncbi.nlm.nih.gov/pubmed/23846003 